\title{
FACTORS AFFECTING COPPER SORPTION AND MOBILITY THROUGH A AND B HORIZON SOILS FROM THE EASTERN SHORE OF VIRGINIA
}

\author{
Hossam Altaher, Andrea Dietrich and John Novak \\ Department of Civil and Environmental Engineering, Faculty of Engineering, Virginia Tech, Blacksburg, USA
}

\begin{abstract}
In this research the copper mobility through the A- and B-horizon of Bojac sandy loam was studied. This study included both batch and column processes. The effects of $\mathrm{pH}$, total organic carbon (TOC) and humic substances were investigated. The mobility of copper was found to be higher through A-horizon soil. The $\mathrm{pH}$ was found to have a considerable effect on the mobility of copper and TOC. The highest mobility of copper was achieved at $\mathrm{pH} 6.24$ and its mobility through both soil horizons was associated with the mobility of TOC. A study of the humic substances indicated that fulvic acids had 4 times higher sorption capacity for copper than humic acids. The association between fulvic acids and copper, coupled with the mobility of TOC and fulvic acids in the soil, accounted for transport of copper through soil columns.
\end{abstract}

KeYWORDs: Copper sorption, Soil, Mobility, TOC, pH

\section{INTRODUCTION}

Agricultural practices constitute important non-point sources of heavy metals in soil, water and air. The main sources of this type of pollution are impurities in fertilizers, pesticides, wood preservatives and corrosion of metal objects like metal roofs and fences [1]. In a green house study, copper applied at 3.8 $\mathrm{kg} \mathrm{Cu} / \mathrm{ha}$ to plasticulture tomato fields to protect against plant disease, remained in the field sorbed to the soil following simulated rainfall. Only $1 \%$ of the copper that was applied left the field. Of this $1 \%, 82 \%$ was in the runoff at concentrations of approximately $200 \mu \mathrm{g} / \mathrm{l}$ dissolved copper and $18 \%$ was in the ground water at a concentration of about 200 $\mu \mathrm{g} / \mathrm{l}$ dissolved copper [2]. A comparison of aqueous copper concentrations in agriculture and non-agriculture watersheds showed that the aqueous copper concentration was higher (up to $126 \mu \mathrm{g} / \mathrm{l}$ dissolved copper) where agriculture was practiced, but less than $5 \mu \mathrm{g} / \mathrm{l}$ dissolved copper in a non-agricultural watershed [3]. Heavy metal contamination of two Chesapeake Bay tributaries on the Eastern Shore of Maryland came from both points (sewage treatment plant) and nonpoint (agriculture runoff) sources [4]. Copper is added to the diet of some growing animals at levels up to $250 \mathrm{ppm}$ to increase their growth rate and promote feed conversion efficiency. When manure produced by these animals is applied to agriculture soils, an increase in soil copper concentration results [5].

\subsection{MOBILITY OF COPPER THROUGH SOIL}

The mobility of most heavy metals in the soil and subsoil depends on the physico-chemical properties of the solid and liquid phases [6]. Trace metals can be found in particulate, 
colloidal and truly dissolved phases. The fate and transport of metals in the environment depends on these phases and the interaction between them. Soil parameters, such as $\mathrm{pH}$, organic carbon content, iron and manganese oxide content and total metal content, affect the distribution of copper and cadmium between different soil fractions [7 and 8].

Lazerte et al. [9] reported two patterns of trace metal transport. One was related to the metal affinity for dissolved organic carbon and the other was due to the metals solubility in dilute acid and mineral soils. Kuo and Parkin [10] suggested that soluble microbial products have a role in heavy metal mobility through formation of metal complexes. Colloidal dissolved organic carbon (DOC) may play the same role. These organics are thought to transport the contaminants between particulate and dissolved phase [11 and 12]. Soil contaminants can travel for long distances through the soil due to the effect of colloidal substances. The mobility of natural colloids was proved by the presence of humic substances in deep aquifer [13]. Borg and Johansson [14], like Gallagher et al. [2], reported that copper is largely retained in the soil. They reported that the mobility increased with the decrease of $\mathrm{pH}$. They suggested that the mobility of copper was associated with the transport of organic material since the copper was highly adsorbed to organic matter rather than soil solids. Grout et al. [15] reported silica as the main component of colloids during period of dry weather flow and at the maximum of the storm water flow. Carbon became the dominant component at the beginning and declining stages of the storm events.

The mobility of heavy metals, including copper, may be enhanced by the formation of inorganic complexes. Chloride for example can form complexes with many cations such as $\mathrm{Cd}$ (II), $\mathrm{Hg}$ (II), PB (II), Zn (II) and $\mathrm{Cu}$ (II). This complex formation mechanism is important, especially in saline soils. Salting of roads for deicing purposes is an important source for chloride ions [16]. The mobility of copper in the soil may also be enhanced by artificial organic compounds that serve as complexing agents for copper. An example of one of these compounds is nitriloacetic acid, which is used as a substitute of some detergents. Howell and Gawthorne [17] pointed out the important role that organic matter plays in the retention and behavior of copper. They reported that both humic and fulvic acids are ligands for binding of copper (II) and that the fulvic acids are the more soluble. Also simple aliphatic acids, amino acids and aromatic acids act as chelating agents for copper (II). The organic complexes of copper, according to their survey, accounted for more than $90 \%$ of the copper solution in the surface horizon.

Bahaminyakamwe et al. [18] found a relation between the mobility of copper and the organic content due to the presence of sewage sludge in such soils Igloria et al. [19] mentioned the possibility of forming complexes between heavy metals and organic matter colloids in solutions, as well as those attached to soil surfaces. This complex formation process increases the concentration of metals in the mobile phase, which allows their transport over long distances. Sposito [20], on the other hand, claimed that the effect of these colloids might be the retardation of the transport of metals.

Brown et al. [21] studied the effect of alkalinity on the metal mobility and found that the mobility of most metals increases with an increase in $\mathrm{pH}$. The authors reasoned that these metals formed mobile fulvic acid metal complexes. When the soil $\mathrm{pH}$ increased the solubility of fulvic acids increased, thus 
promoting the formation of more fulvic acid complexes.

\section{OBJECTIVES}

The goal of this research was to study the mechanisms of copper mobility through different soil horizons of Bojac sandy loams.

\section{MATERIALS AND METHODS}

\subsection{SOIL USED AND ITS PROPERTIES}

The soil used for this study was undisturbed Bojac sandy loam. It was obtained either from the town of Exmore, Virginia or from Parksley, Virginia. The A-horizon soil was obtained from depth ranging from 0 to 18inches. The A-horizon soil had a strong brown color, a sandy loam or loam texture and moderately rapid permeability. The soil excavated to a suitable depth to get the Bhorizon soil samples.

The B-horizon at this depth was obviously color differentiated from the A-horizon. The color of B-horizon soil was light brown compared with dark brown for the A-horizon soil. No special treatment was applied for this soil before use except for drying. The soil was sieved before adsorption processes. Only the fraction $<2 \mathrm{~mm}$ was used. The soil was not disturbed or tilled before.

\subsection{SOIL ANALYSIS}

The soil used was analyzed for organic matter $(\mathrm{OM}), \mathrm{pH}$, and some elements $(\mathrm{Ca}, \mathrm{Mg}, \mathrm{P}, \mathrm{K}$, $\mathrm{Zn}, \mathrm{Mn}$ and $\mathrm{Fe}$ ). The result of this analysis is presented in Table (1).

TABle 1: Chemical Characteristics of THE SAND AND Bojac SANDy LOAM

\begin{tabular}{|c|c|c|c|c|c|c|c|c|c|}
\hline \multirow[b]{2}{*}{ 1) Sample } & \multirow[b]{2}{*}{$\mathrm{pH}$} & \multirow[b]{2}{*}{$\% \mathrm{OM}$} & \multicolumn{7}{|c|}{ Chemical Concentration (ppm) } \\
\hline & & & $\mathrm{P}$ & $\mathrm{K}$ & $\mathrm{Ca}$ & $\mathrm{Mg}$ & $\mathrm{Zn}$ & $\mathrm{Mn}$ & $\mathrm{Fe}$ \\
\hline & 5.6 & 0.01 & 0.94 & 2.78 & 52.3 & 10.02 & 0.21 & 0.64 & 1.83 \\
\hline B-horizon & 7.4 & 1.09 & 4.36 & 23 & 1335 & 40.48 & 1.08 & 21.89 & 6.32 \\
\hline A-horizon & 6.7 & 3.29 & 10.3 & 57.3 & 1735 & 96.24 & 3.72 & 38.05 & 7.51 \\
\hline
\end{tabular}

It is clear from the analysis that the higher organic carbon content $(\mathrm{OM})$ is in the Ahorizon soil compared with the B-horizon soil.

\subsection{CHEMICALS AND APPARATUS}

All chemicals and reagents used for this study were analytical grade or trace metal grade. Nanopure ${ }^{\circledR}$ water was used for all reagent preparation and subsequent dilution unless otherwise is mentioned. The copper solutions were prepared by diluting copper reference solution $(1 \mathrm{mg} / \mathrm{ml})$ obtained from Fisher using Nanopure ${ }^{\circledR}$ water. The containers, glassware, funnels and pipettes used in the analysis were soaked in 10\% trace metal grade nitric acid for at least 8 hours, rinsed with distilled water three times followed by rinsing with Nanopure ${ }^{\circledR}$ water three times. The glassware (except for volumetric flasks) was oven dried at $102^{\circ} \mathrm{C}$; plasticware and volumetric glassware were air-dried.

The containers used for batch adsorption processes were tested for copper adsorption by shaking copper solution in 8 glass conical flasks and 6 plastic bottles for 24 hours. 
No copper was released or sorbed by those containers. The clear rigid PVC plastic columns used for continuous study were purchased from United States Plastic Corp. They were not tested for copper adsorption but the information obtained from the manufacturer indicated that their material did not adsorb copper and it is not affected by the acidic solutions.

\subsection{COPPER SORPTION BY FILTRATION PAPER}

During copper filtration studies, there was concern that copper was being retained on the filter paper. Therefore, copper losses during filtration were quantified for a variety of filter types. Three samples of copper solution of $400 \mu \mathrm{g} / \mathrm{l} \mathrm{Cu}{ }^{2+}$ and $\mathrm{pH} 6$ were passed through $0.45 \mu \mathrm{m}$ membrane filters from different companies and through G6 filters. The initial and final concentrations of copper were measured. About $0.7 \%$ of copper loss was noticed for the $0.45 \mu \mathrm{m}$ Gelman membrane filters whereas very high loss (65\%) was detected in the case of G6 filters. Variable copper adsorption was noticed for other filters. For this reason Gelman $0.45 \mu \mathrm{m}$ membrane filters were used for all filtration processes.

\subsection{COPPER ANALYSIS}

The dissolved copper analysis was performed according to Standard Methods for the Examination of Water and Wastewater, number 3030 B (APHA 1995). The device used was a Perkin Elmer 703 Atomic Absorption Spectrophotometer (Flame Atomic absorption), with a range of 100 to $5000 \mu \mathrm{g} / \mathrm{l}$. The wavelength used was 324.8 $\mathrm{nm}$ and slit setting was adjusted to $0.7 \mathrm{~nm}$. For copper concentration $100 \mu \mathrm{g} / \mathrm{l}$ and lower, a Perkin Elmer Zeeman 5100 HGA Graphite furnace atomic absorption spectrophotometer was used. The samples were diluted with Nanopure ${ }^{\circledR}$ water when necessary. All the samples were acidified with a $1: 1 \quad \mathrm{HNO}_{3}$ solution to below $\mathrm{pH} 2$ and stored at approximately $4^{\circ} \mathrm{C}$.

\subsection{BATCH ADSORPTION PROCESSES}

Two methods were used to perform the batch adsorption studies. In the first method, the weight of the adsorbent (air dried Bojac sandy loam soil) was changed and the concentration of the adsorbate (copper solution) was kept constant. In all the experiments the $\mathrm{pH}$ of the copper solution was adjusted to 6 using $\mathrm{HNO}_{3}$ and $\mathrm{NaOH}$. This was done by preparing a stock solution of the required concentration, adjusting its $\mathrm{pH}$ and then placing $100 \mathrm{ml}$ aliquots of this solution in acid-washed conical flasks. The stock solution was freshly prepared for each adsorption experiment. Different initial concentrations (23.6 and $247 \mu \mathrm{g} / \mathrm{l}$ ) of the copper solution were used as the adsorbate. Each experiment included 10 different soil weights from 0.1 to $3 \mathrm{~g}$ (weighed to the fourth decimal point). A volume of $100 \mathrm{ml}$ of copper solutions was added to the flasks and then shaken on a reciprocal shaker for 24 hours at $20^{\circ} \mathrm{C}$ temperature, which was sufficient to achieve equilibrium [22]. To measure the final copper concentration of the solutions, approximately $10 \mathrm{ml}$ were taken from each flask, filtered through $0.45 \mu \mathrm{m}$ membrane filters and analyzed for copper using an atomic absorption spectophotometer. The rest of the solutions were allowed to settle for 2-5 days and samples were taken of the clear liquid and copper was measured.

The second batch test method involved the change of concentration of the copper solution with the weight of soil kept constant. The range of copper concentration of this set was from $47 \mu \mathrm{g} / \mathrm{l}$ to $416 \mu \mathrm{g} / \mathrm{l}$. The weight of soil was one gram (to the fourth decimal point). A volume of $100 \mathrm{ml}$ was used and the $\mathrm{pH}$ values were adjusted to 6 using $\mathrm{NaOH}$ 
and $\mathrm{HNO}_{3}$. After shaking 24 hours on a rotary shaker at $20^{\circ} \mathrm{C}$, a sample was taken, filtered through $0.45 \mu \mathrm{m}$ membrane filter, and analyzed for copper. The rest of the solution in each flask was left to settle for 2 days and then copper was measured in the clear liquid of each flask.

\subsection{SOIL ORGANIC MATTER}

The soil organic substances (fulvic acids humic acids and humin) were extracted by the method adopted from Page et al. [23]. This method involved the extraction of different organic materials according to their solubility in acids and alkalis.

The total organic carbon (TOC) was measured on acidified liquid samples that were purged with oxygen for five minutes to remove the inorganic carbon. TOC was then measured by the UV assisted persulfateoxidation method with infrared detection of the evolved carbon dioxide. The instrument used was Dorham Carbon Analyzer DC-80.

\subsection{Continuous Process}

Continuous flow column experiments were conducted to simulate the field conditions. Two columns were filled with Bojac loam soil (A horizon). Each column had three sections. The lower section was filled with graded gravel to prevent the soil from being washed out. The height of this section was about $6 \mathrm{~cm}$. The second section contained $19 \mathrm{~cm}$ of soil that was air dried and sieved to be less than $2 \mathrm{~mm}$. A soil mass of $250 \mathrm{~g}$ was used. After adding each fraction, the soil was pressed using a wooden rod covered with plastic sheet to avoid the contamination of the soil. This pressing process was continued until no further consolidation was observed. According to Newman et al. [24], columns would have porosity of $30 \%$ (s.d. $\pm 6 \%$ ) if packed with this technique. The third section served as a reservoir for the copper solution. No metal parts were used in the column to avoid any possible contamination. A schematic diagram of the used column is illustrated in Fig.1. The design of the column was adopted from the work of Igloria et al. [19].

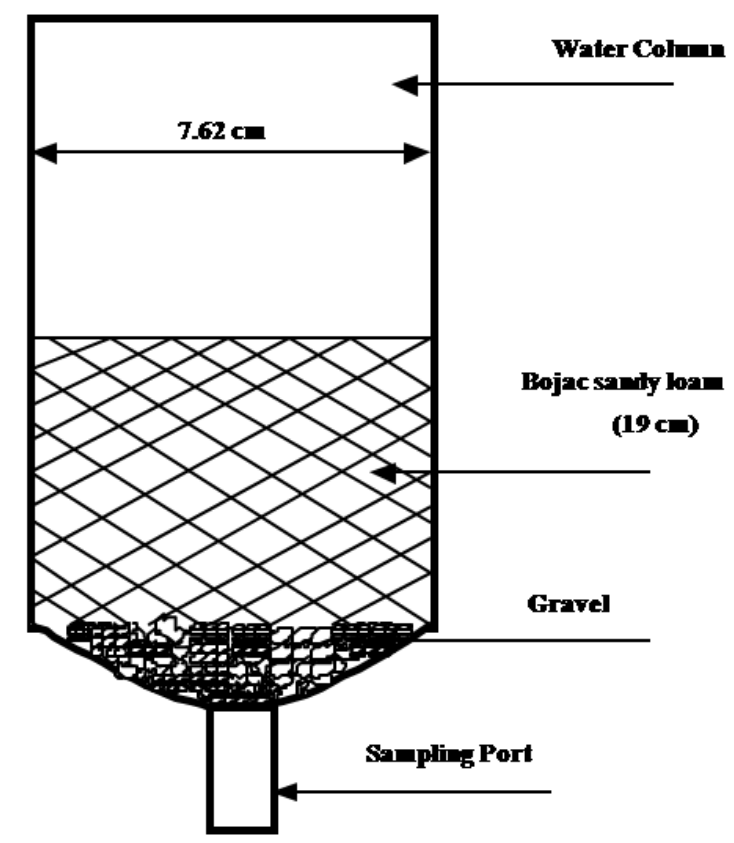

Fig.1. Schematic Diagram of the Soil Column

The column was fed with one volume of $\mathrm{pH}$ 6 copper solutions, i.e. instantaneous pulse input. Effluent samples were collected from the bottom of the column at different time intervals; sampling continued until no significant copper was measured in the effluent. A freshly packed column was used for each run. The samples were analyzed for copper and TOC.

\subsection{EFFECT OF PH CHANGE ON MOBILITY OF COPPER THROUGH B-HORIZON}

To accelerate the rate of copper mobility through the B-horizon soils, clean sand was mixed with the soil. Sand was first treated by washing several times with water. It was then placed in a muffle furnace for four hours to remove any organic substances. The sand was mixed with B-horizon soil in a ratio of $8: 2$ (soil: sand). Three columns were packed with 
$300 \mathrm{~g}$ each of this mixture. The columns were tapped several times after addition of each portion to achieve consolidation. Three copper solutions $(1200 \mathrm{ml}$ each) having the same copper concentration $(400 \mu \mathrm{g} / \mathrm{l})$ and different $\mathrm{pHs}(4.24,6.25,7.25)$ were added to the three columns. Effluent samples were collected from the bottom of each column and analyzed for copper and TOC.

\subsection{MOBILITY OF COPPER THROUGH DIFFERENT SOIL LAYERS}

In this experiment the mobility of copper through the combined A and B horizons was studied and compared to mobility through the separate A and B layers. Three columns were used for this experiment. The first one was packed with $300 \mathrm{~g}$ of a mixture of Ahorizon soil and sand (8:2 ratios, respectively). The second column was packed with $300 \mathrm{~g}$ of mixture of B-horizon soil and sand (8:2). The third column consisted of both the $\mathrm{A}$ and $\mathrm{B}$ layers. The bottom layer was $150 \mathrm{~g}$ of mixture of B-horizon soil and sand (8:2) and the upper layer was $150 \mathrm{~g}$ of a mixture of Ahorizon soil and sand (8:2). A volume of $300 \mathrm{ml}$ of copper solution $(400 \mu \mathrm{g} / \mathrm{l}$ and $\mathrm{pH}$ ) was added to each column as pulse input. Effluent samples were collected from the bottom of each column and analyzed for copper and TOC.

\subsection{EFFECT OF IONIC STRENGTH ON COPPER SORPTION}

Both A- and B-horizon soils used for this experiment were air-dried, crushed and sieved through a $2 \mathrm{~mm}$ sieve before usage. A copper nitrate solution was prepared with a concentration of $400 \mu \mathrm{g} / \mathrm{l}$ and its $\mathrm{pH}$ was adjusted to 6 . One hundred $\mathrm{ml}$ aliquots of this solution were placed in acid washed bottles. Sodium nitrate (solid form) was added to the bottles to reach sodium nitrate concentrations ranging from 0.001 to 0.025 mole/l. The conductance of each solution was measured using YSI Model 32 Conductance Meter by Scientific Division, Yellow Springs Instrument Co., Inc. Approximately the same weight (1.2 g) of either A- or B- horizon soil was added to each bottle. The bottles were shaken for 24 hours at $20^{\circ} \mathrm{C}$. The final $\mathrm{pH}$ and the final conductance of each solution were measured. The solutions were filtered through $0.45 \mu \mathrm{m}$ membrane filter acidified to $\mathrm{pH}<2$ with $\mathrm{HNO}_{3}$ and the concentration of copper in the filtrate was measured.

\subsection{EFFECT OF CHLORIDE IONS ON COPPER SORPTION}

The same technique applied for studying the ionic strength effect was used to study the effect of chloride ions on copper mobility. A $400 \mu \mathrm{g} / \mathrm{l}, \mathrm{pH} 6$ copper solution was also used. Similar weights of the A- and B-horizons were added to the copper solution $(1.2 \mathrm{~g})$. The concentration range $(0.001-0.025 \mathrm{~mol} / \mathrm{l})$ of sodium chloride salt that was applied to the copper solutions was similar to the concentrations of sodium nitrate that were used in the ionic strength experiment. That allowed a further comparison between the effect of ionic strength and chloride ions on the copper removal on both soil horizons.

\subsection{Size OF ORganic SUbSTANCES BINDING COPPER}

To further investigate the role of colloidal particles, gel chromatography was utilized to separate the different fractions contained in the effluent samples from the soil/copper columns. About $1.5 \mathrm{ml}$ of the effluent samples from the soil columns were placed on a $25 \mathrm{~cm}$ x $1.2 \mathrm{~cm}$ (i.d.) column containing Sephadex (G-25). The samples were eluted with Nanopure ${ }^{\circledR}$ water until the copper concentration in the Sephadex column effluent was negligible. Both copper and TOC concentrations were measured for the eluted samples. The molecular weight range of the organic carbon was characterized by 
eluting $1.5 \mathrm{ml}$ of Bovine Serum Albumin though the Sephadex G-25 column under the same conditions.

\subsection{GEL CHROMATOGRAPHY OF HUMIC SUBSTANCES}

The column used for conducting this experiment was a volumetric burette fitted with a piece of glass wool at the bottom to prevent the Sephadex G-25 gel from escaping the column. The dimensions of this column were $25 \mathrm{~cm} \times 1.2 \mathrm{~cm}$ i.d. The exclusion limit of such column is about 5000 Daltons [25]. Thirteen $\mathrm{ml}$ of aqueous gel solution (Sephadex G-25) was placed in the column and was allowed to settle until the two phases were separated and no noticeable decrease of the gel height was noticed. A 1:1 mixture of humic substances (humic or fulvic): copper nitrate was prepared and allowed to equilibratefor 24 hours. $2 \mathrm{ml}$ of this mixture was placed on the gel surface using micropipette and Nanopure ${ }^{\circledR}$ water was added as eluent. The flow rate was approximately $0.5 \mathrm{ml} / \mathrm{min}$. About $1.5 \mathrm{ml}$ aliquots were collected from the bottom of the column using automatic collector. The collection of samples was continued until no further copper was detected in the effluent.

\subsection{KINETICS OF HUMICS COPPER INTERACTION}

The concentration of copper during reaction with humic substances was measured as free copper using copper selective electrode (Orion ${ }^{\circledR}$ cupric electrode, Orion ${ }^{\circledR} \mathrm{D} /$ junct. reference electrode and Beckman $\Phi 12$ $\mathrm{pH} / \mathrm{ISE})$. The $\mathrm{pH} / \mathrm{ISE}$ meter was calibrated with three copper nitrate standard solutions $(0.1,0.5$ and $0.9 \mathrm{mg} / \mathrm{l})$ before each set of measurements. Sodium nitrate solution (4 Molar) was added to the standard solution to achieve a concentration of $2 \mathrm{mM}$ in each standard. The role of sodium nitrate was to provide the electrolyte necessary for measurement. The $\mathrm{pH}$ of the standards was adjusted at six using $\mathrm{NaOH}$ and $\mathrm{HNO}_{3}$. Fifty $\mathrm{ml}$ of copper nitrate solution of $\mathrm{pH} 6$ and initial concentration of $0.9 \mathrm{mg} / \mathrm{l}$ were placed in acid-washed polyethylene bottles. Soil-extracted humic acids $(0.8 \mathrm{ml}$ of 613 $\mathrm{mg} / \mathrm{l}$ ) were added to the bottle to achieve humic acids concentration of $10 \mathrm{mg} / \mathrm{l}$. The free copper concentration was measured over time using the copper selective electrode until equilibrium was reached (indicated by no further change of copper concentration). The free copper concentration was measured as millivolts and converted to $\mathrm{mg} / \mathrm{l}$ using the calibration curve. The copper concentration was measured after 24 hours to be sure that equilibrium was reached. The same procedure was applied for measurement of copper-fulvic acids kinetics but the fulvic acids were added to reach concentration of $10 \mathrm{mg} / \mathrm{l}$ as TOC.

\subsection{ADSORPTION ISOTHERMS FOR COPPER ON HUMIC SUBSTANCES}

A stock solution of copper nitrate was prepared and its $\mathrm{pH}$ was adjusted to 6 . The initial concentration of this solution was 0.8 $\mathrm{mg} / \mathrm{l}$ and this concentration was checked by the copper selective electrode. $50 \mathrm{ml}$ aliquots of this solution were placed in acid-washed polyethylene bottles. Different volumes of fulvic acids were added to each bottle to achieve a concentration range from 1.5 to 19 $\mathrm{mg} / \mathrm{l}$ as TOC. The bottles were capped and shaken for 24 hours at room temperature. The final copper concentration for each bottle was measured using the copper selective electrode. The amount of copper adsorbed or reacted was calculated as the difference between the initial and final copper concentration. A similar experiment was performed for sorption of copper to humic acids. The experiment was performed in duplicate. 


\section{RESULTS AND DISCUSSION}

\subsection{BATCH ADSORPTION}

The purpose of this experiment was to define the adsorption capacity of A-horizon soil for copper and attempt to evaluate the mechanism for this sorption. Some of batch adsorption results for A-horizon soil are shown in Figures (2) and (3). Based on literature results and the results of these experiments, the suggested mechanism is the attachment of copper ions to the organic substances contained in the soil. The basis of this proposed mechanism is explained below.

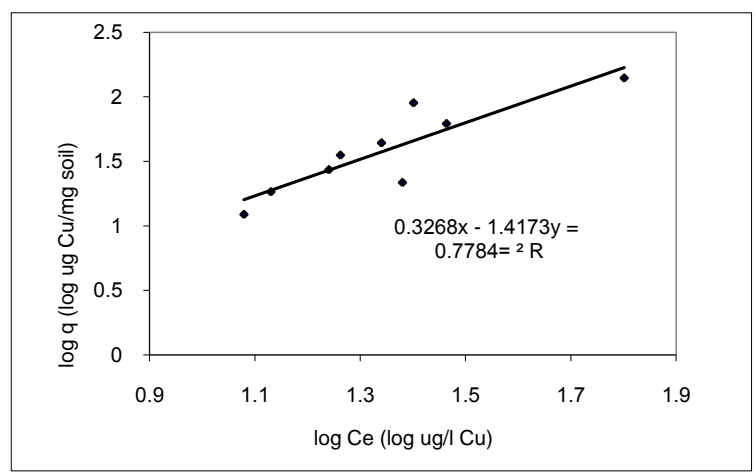

Fig.2. Freundlich Adsorption Isotherm on A-horizon soil (change of soil weight). The initial copper concentration was $247 \mu \mathrm{g} / \mathrm{l}$ and its $\mathrm{pH}$ was 6 . No filtration was applied. The soil solution was allowed to settle for $\sim 48$ hours to separate the soil.

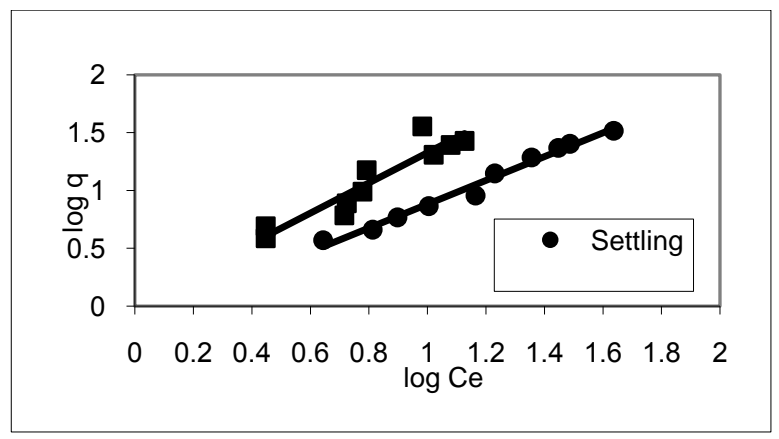

Fig.3. Freundlich adsorption isotherm (change of copper conc) at $\mathrm{pH} 6$. The solution was either filtered through $0.45 \mu \mathrm{m}$ filters or allowed to settle for 48 hours prior to measurement of copper

The first experimental approach for obtaining adsorption isotherms was to place a copper solution into several flasks at one concentration and vary the amount of soil added. Because of

desorption of TOC from the soil surface, this resulted in an increase in the solution TOC as the soil mass increased. This was clearly observed by an increase in the yellow color of the solution as the soil mass increased. When the soil mass was $3.05 \mathrm{~g}$, the solution TOC was $5.41 \mathrm{mg} / \mathrm{l}$; when the soil mass was $0.56 \mathrm{~g}$ , the TOC was $1.82 \mathrm{mg} / \mathrm{l}$. The increased solution TOC resulted in a decrease in the amount of copper sorbed as the soil mass increased because most of the copper was associated with TOC in solution. This indicated that the copper was strongly associated with solution TOC and not the soil surface. Further, when some of these data were plotted in the form of a Freundlich isotherm, the slope was negative rather than positive. The negative slope, indicating less adsorption as more soil was added, was evident even when the solution was filtered through a $0.45 \mu \mathrm{m}$ filter. The TOC associated copper could be removed from solution only after 48 hours of settling and even then, the removal of TOC associated copper was incomplete. An isotherm for copper is presented in Fig.2., where the soil mass was varied and the copper concentration held constant.

An alternative approach used in this study to obtain an isotherm was to vary the copper concentration and hold the soil mass (and therefore, TOC constant). Data for two such experiments are shown in Fig.3. In one case, the solution was filtered through a $0.45 \mu \mathrm{m}$ filter and in the other; the solution was allowed to settle for 48 hours before measuring the copper. It can be seen from these data that the greatest apparent sorption was for the solution filtered using the $0.45 \mu \mathrm{m}$ filter. A comparison to the isotherm data in 
Figure (2) indicates that the slope of the isotherm is different from the slope obtained for a constant soil mass.

The isotherm data showed that much of the copper was associated with soil organic matter and some of the soil organic matter that binds copper is easily desorbed from the soil. This desorbable organic matter contributes to the mobility of copper and might even be the major mechanism by which sorbed copper can move through soil. On the other hand, the ability to filter or settle the TOCassociated copper also suggests that as this material passes through soil, it may be removed. Both the mobilization of TOCassociated copper and the removal by filtration are expected to depend on the type of soil and composition of the TOC.

\subsection{Column Studies}

The purpose of this portion of the study was to trace the mobility of copper through soil and to determine its association with organic substances. As illustrated in Figures (4) to (8) the copper that was eluted was associated with TOC.

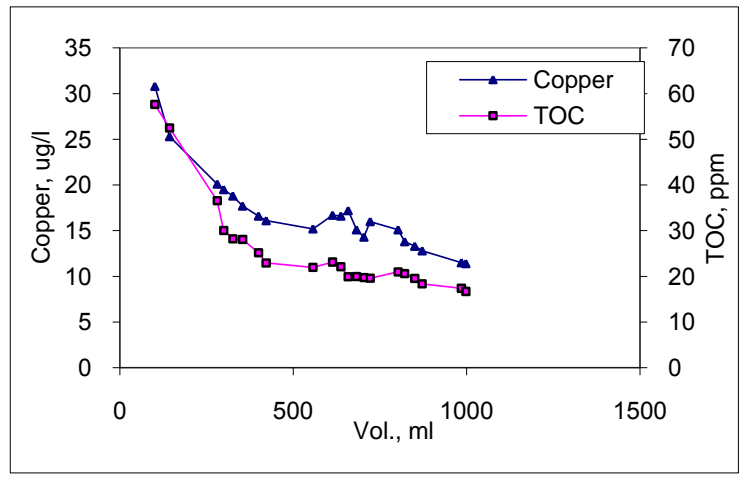

Fig.4. Column Study of copper mobility. The copper was applied as a pulse input with a conc. of $400 \mu \mathrm{g} / \mathrm{l}$ and $\mathrm{pH} 6$ to A-horizon soil. Replicate (1)

This association indicated that the interaction of copper with organic substances present in soil. The copper solution added to these duplicate columns had the same concentration and $\mathrm{pH}(400 \mu \mathrm{g} / \mathrm{l}$ and 6, respectively). Regression analysis for the data from the two columns indicated very high correlation between eluted copper and TOC ( $\mathrm{p}<0.001)$ for both columns. Borg and Johanson [ observed the same effect of organic material on the transport of copper. They suggested that the adsorption of copper on these materials was a mechanism of interaction. Some researchers specified fulvic acids as the main organic substances responsible for this mobility [9 and 18]. On the other hand, others have a different opinion. McCarthy and Zachara [26] concluded that natural organic matter did not facilitate the mobility of copper. Igloria et al. [19] claimed that organic matter decreased the mobility of some heavy metals including copper. They attributed that to a high affinity of the organic substances to the soil, and in turn, the metals to the organic substances. The reason for the differences could be the different soil types and organic loadings that were used in these studies. This suggests that different soil properties and different organic substance structures and properties can give widely different metal mobilities. Data for the gel chromatography is shown in Figure (6). All the samples taken from the columns indicated the interaction between copper and TOC. The peaks were broad, indicating high dispersion of molecular weight of the compounds eluted from the columns. The copper and organic substances were eluted following a discharge of 7-9 $\mathrm{ml}$, similar to the BSA marker used to identify the molecular size range as illustrated in Figure (8). Analyzing the data using Minitab indicated the high correlation between copper and TOC $(\mathrm{p}<0.001)$. The exclusion limit of this column (5000 daltons) lies in the molecular weight range of both fulvic acids and humic acids. The results of the kinetics and adsorption isotherms of the humic substances 
suggest fulvic acids as the main substance responsible for the copper mobility. This phenomenon was further studied and will be addressed in the next section of the paper.

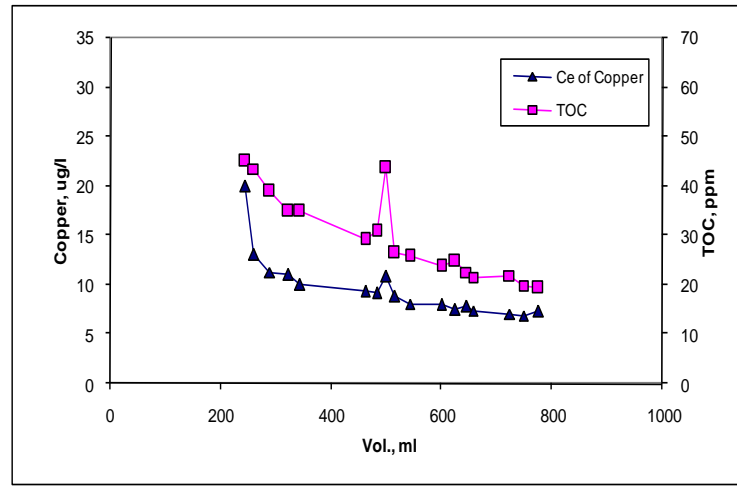

Fig.5. Column Study of copper mobility. The copper was applied as a pulse input with a conc. of $400 \mu \mathrm{g} / \mathrm{l}$ and $\mathrm{pH} 6$ to A-horizon soil. Replicate (2).

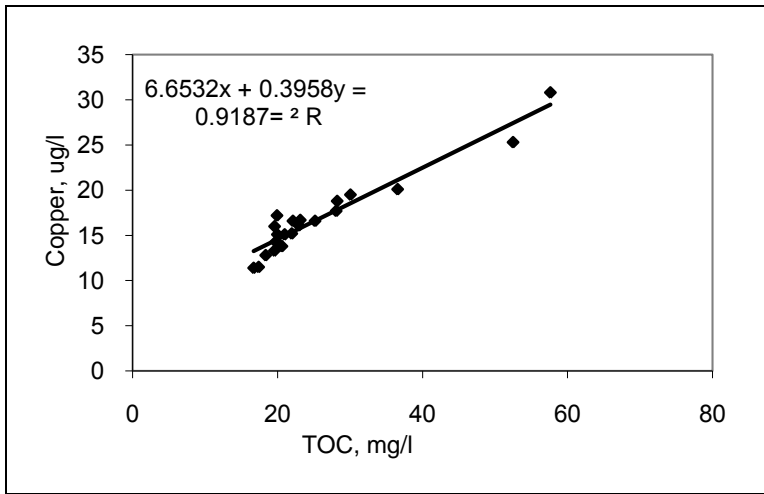

Fig.6. Relation between copper and TOC during copper mobility through A-horizon soil. Initial copper concentration was $400 \mu \mathrm{g} / \mathrm{l}$ and its $\mathrm{pH}$ was 6 . Replicate 1

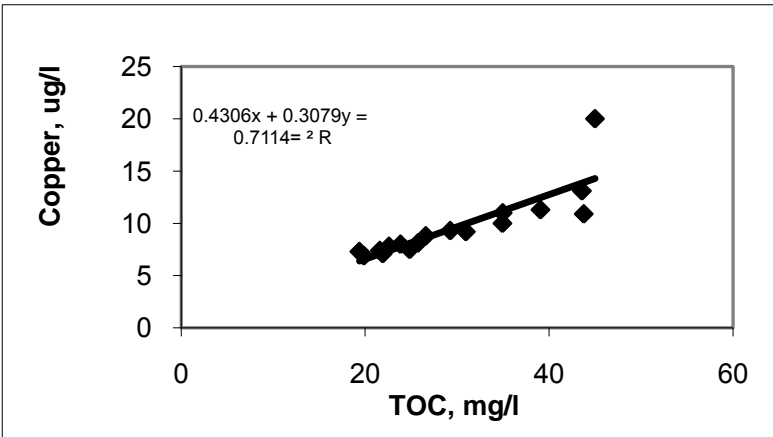

Fig.7. Relation between copper and TOC during copper mobility through A-horizon soil. Initial copper concentration was $400 \mu \mathrm{g} / \mathrm{l}$ at $\mathrm{pH}$ 6, Replicate 2 .

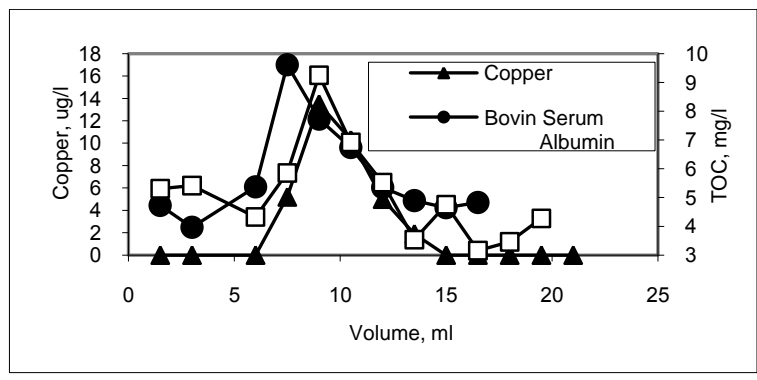

Fig. 8. Gel Chromatography of copper compounds from soil column. Samples were obtained from the column depicted by the data in Figure (5)

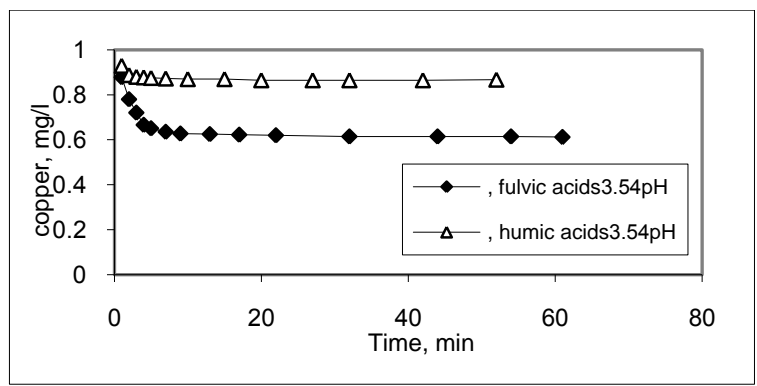

Fig.9. Kinetics of Humic substances-Copper Interaction at $\mathrm{pH} 3.54$. Initial copper concentration was $0.9 \mathrm{mg} / \mathrm{l}$. Initial humic and fulvic acids concentration was $10 \mathrm{mg} / \mathrm{l}$ as TOC

\subsection{KINETICS OF HUMICS-COPPER INTERACTION}

As a further investigation of the role of humic substances on the copper binding and mobility, several kinetics experiments were conducted. As mentioned in the procedures section, the humic acids used were extracted from the A-horizon soil. The results of copper-humics interaction are illustrated in Figure (9). The kinetics of fulvic acids reaction with copper indicates a fast rate with approximately $60 \%$ of the copper bound within the first 5 minutes. On the other hand, little change in copper concentration in the humic acids solution was observed even after 24 hours. Kramer and Duinker [27] observed similar results with humic and fulvic acids extracted from intertidal sediments. The fulvic acids fraction of their extract showed fast sorption whereas humic acids showed little if any sorption within the 3 hours measurement time. El-Sayed et al. [28], on 
the other hand, found that the amount of copper in humic acids was higher than that of fulvic acids extracted from the bottom sediments of Lake Edfu, Egypt. However, a study that was performed in another Egyptian Estuary (Mahakam Estuary) found that the amount of copper associated with fulvic acids was higher than that associated with humic acids. These differences may be due to several factors including differences in the chemical makeup or functional groups associated with these organics, modification during transportation through different mediums and post depositional alterations.

TABLE 2: EQUILIBRIUM CONCENTRATION OF COPPER WHEN REACTING WITH DIFFERENT HUMIC SUBSTANCES AT DIFFERENT PHS

\begin{tabular}{|c|c|c|}
\hline \multirow{2}{*}{$\mathrm{pH}$} & \multicolumn{2}{|c|}{ Copper concentration, $\mathrm{mg} / \mathrm{l}$} \\
\cline { 2 - 3 } & 3.54 & 6 \\
\hline fulvic acids & 0.6 & 0.6 \\
\hline humic acids & 0.85 & .82 \\
\hline
\end{tabular}

4.4 ADSORPTION ISOTHERMS OF COPPER ON ORGANIC MATTER

The results of the adsorption isotherms, illustrated by Figure (10), agree with that of the kinetics experiments. The humic acids had very low adsorption (data not shown), if any, whereas the fulvic acids had a high adsorption capacity. Stevenson and Chen [29] found that complexes formed between humic acids and copper were stronger than those formed between fulvic acids and copper. That means if the copper-humic complexes are formed, then the copper will be less mobile. The results of this research indicated that fulvic acid was the major chelating agent or adsorbing site of copper and that might describe the high mobility of copper.

4.5 EFFECT OF CONDUCTIVITY ON COPPER ADSORPTION

The conductivity change achieved by changing the concentration of sodium nitrate did not have a significant effect on the batch adsorption capacity of soil towards copper. The concentration range used was 100-2000 $\mathrm{mg} / \mathrm{l} \mathrm{NaNO} 3$ corresponding to conductance in the range of $0.15-2.35 \mathrm{mmoh}$. The same result was noticed for both $\mathrm{A}$ - and B-horizon soil. The change in adsorption capacity due to change of conductance was negligible. A very slight increase in conductance was noticed after the equilibrium time for both soil horizons. Another observation was the increase of the $\mathrm{pH}$ of the solution from 6 to 8 in case of A-horizon and from 6 to 7.4 in case of $\mathrm{B}$-horizon. This increase in $\mathrm{pH}$ was noticed in other experiments including column and batch studies.

This increase of $\mathrm{pH}$ may be attributed to leaching of alkaline substances from the soil.

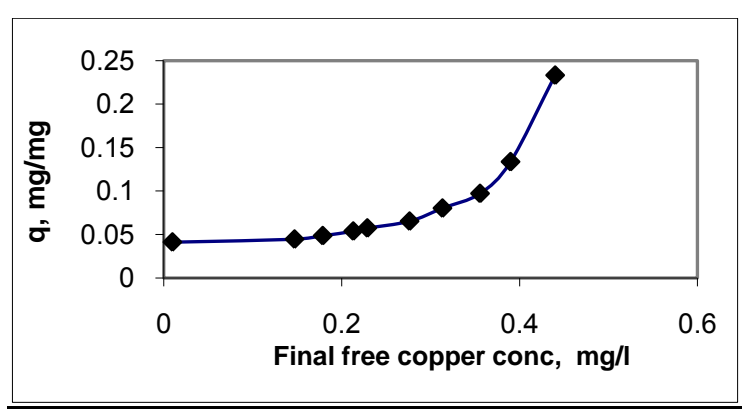

Fig.10. Adsorption Isotherm of Copper on Soil Fulvic acids. Initial copper concentration was $0.8 \mathrm{mg} / \mathrm{l}$ at $\mathrm{pH} 6$. The fulvic acids concentration ranged from 1.5 to $19 \mathrm{mg} / \mathrm{l}$

\subsection{EFFECT OF CHLORIDE IONS ON COPPER ADSORPTION ON BOTH A- AND B-HORIZON SOILS}

The chloride ion concentration did not have a major effect on the copper adsorption on either A- or B-horizon soils. Very slight difference in adsorption capacity of copper on these two horizons was noticed under the effect of chloride (the difference was in the range of $0.25 \mu \mathrm{g} / \mathrm{g}$ ). That suggests that there is a minor effect of chloride ions on this type of soil and over the concentration range of 100 to $2000 \mathrm{mg} / \mathrm{l} \mathrm{NaCl}$. The formed substances would stay in the soluble form and would not 
adsorb on the soil surface, which may explain why the adsorption capacity did not increase with the increase of chloride ions concentration.

\subsection{EFFECT OF PH ON COPPER MOBILITY THOUGH B-HORIZON SOIL}

Three columns were run to study the effect of different $\mathrm{pH}$ levels on copper mobility through B-horizon soil. The results of this experiment are indicated in Figures (11) and (12). It is clear from the figures that changing the $\mathrm{pH}$ of the applied solution has a significant effect on the mobility of both copper and TOC. The lowest copper and TOC mobility was achieved at $\mathrm{pH} 4.24$ whereas the highest mobility of copper was achieved at $\mathrm{pH}$ 6.24. These results agree well with that obtained for the A-horizon soil (data not shown). The highest copper mobility is not in complete agreement with the highest TOC mobility. As seen from Figure (12), the highest TOC mobility was

achieved at $\mathrm{pH} 7.24$ and although this $\mathrm{pH}$ did not yield the highest copper mobility, the pattern for TOC and copper were in very good agreement. In general, the change in $\mathrm{pH}$ has an effect on both TOC and copper mobility. Within the range tested, the higher the $\mathrm{pH}$, the higher was the mobility of copper and TOC.

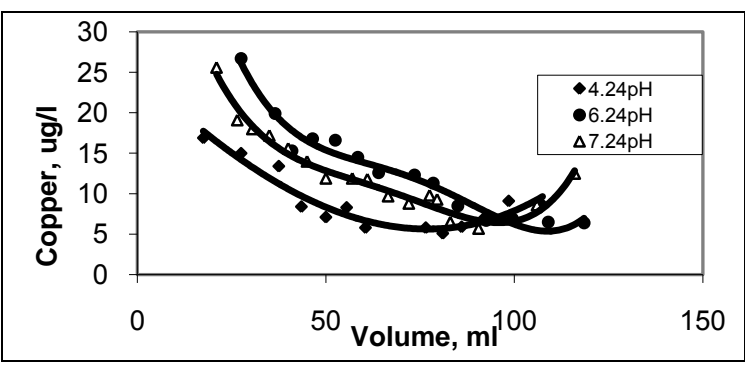

Fig.11. Effect of $\mathrm{pH}$ change on mobility of copper through air-dried B-horizon soil. Initial copper conc. was $400 \mu \mathrm{g} / 1$

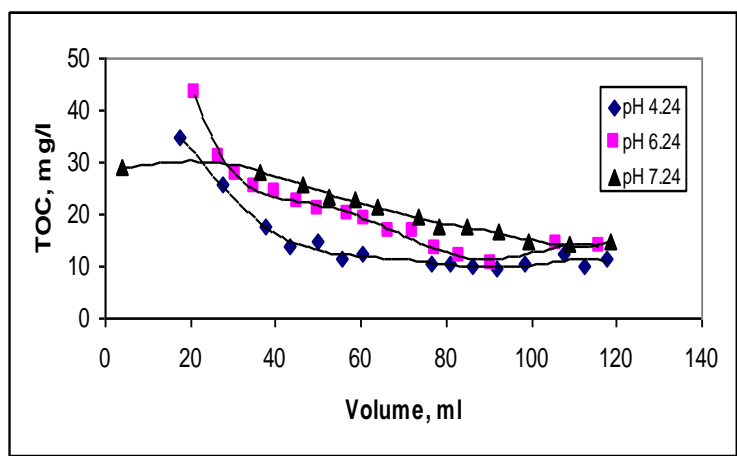

Fig.12. Effect of $\mathrm{pH}$ change on mobility of TOC through air-dried B-horizon soil, initial copper conc. was $400 \mu \mathrm{g} / \mathrm{l}$, and its $\mathrm{pH}$ was 6

The effect of $\mathrm{pH}$ on this process is sometimes called variable charge effect. This effect of $\mathrm{pH}$ occurs on many components of the soil such as organic matter, oxides, hydroxides, oxyhydroxides and edges of phyllosilicates [30]. As the $\mathrm{pH}$ increases, deprotonation of the surface takes place and $\mathrm{OH}^{-}$ions may cover the soil surface, which may result in the soil surface being negatively charged. The part of the organic substances (TOC) carrying a similar charge would be repelled from the soil surface, thus increasing the mobility of TOC. Another explanation of the effect of $\mathrm{pH}$ was given by Brown et al. [21]. They mentioned that when the soil $\mathrm{pH}$ increased the solubility of fulvic acids increased, thus giving chance for formation of more fulvic acids complexes. Borg and Johanson [14] noticed the same effect of $\mathrm{pH}$. They also suggested that the mobility of copper was associated with the mobility of organic materials because the copper was highly adsorbed on them.

\subsection{COLUMN STUDY OF COPPER MOBILITY THROUGH A AND B HORIZONS}

This experiment was conducted to study the vertical copper mobility through the different soil horizons. The results of this experiment are illustrated in Figure (13). As expected, the concentration of the copper eluted from the column containing the A-horizon soil mixture was much higher than that of the B-horizon 
(3 times) column and the combined A- and B- column (4 times).

The major difference was that of TOC eluted from the double-layers column. The concentration of the TOC from the combined A- and B- column was lower than that of the A-horizon column. Two explanations may be suggested. First, the weight of A-horizon soil in the mono-layer column is double the weight of that soil in the two-layer column, which consequently might lead to this drop in TOC concentration. Second, the attenuation of TOC concentration might be due to sorption or filtration of TOC by the B-horizon layer. Under this scenario it is likely that the TOC flushed out from the A-horizon layer was being retained by on the B-horizon layer as the solution penetrated the soil. This attenuation of TOC concentration did not have a considerable effect on the mobility of copper through these three columns as indicated in Figure (13). That might suggest that not all the mobile TOC could form complexes with copper. In a study of well tilled Bojac sandy loam, Gallagher et al. [2] found similar results. That study indicated that for agricultural soil placed in a $2 \times 4 \times 7 \mathrm{ft}$ soil bin, copper continued to leach through the soil for a 3 month period if rain water was applied to the soil. The continued migration of copper in that simulated study is similar to the results of this research for A-horizon soil.

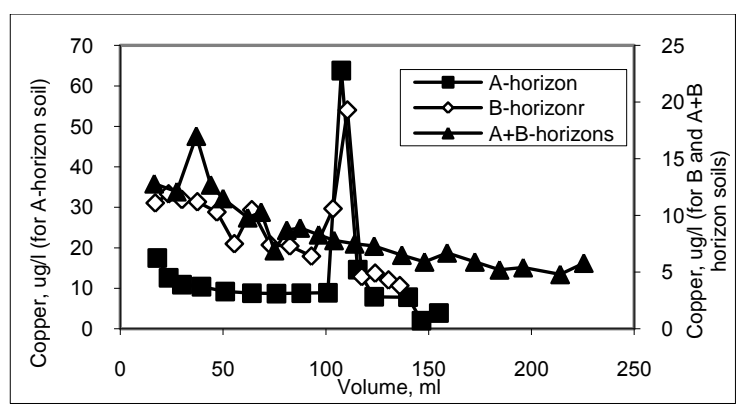

Fig.13. Mobility of Copper through columns containing different dried soil horizons. The concentration of the copper solution was $400 \mu \mathrm{g} / \mathrm{l}$ and its $\mathrm{pH}$ was 6 .

\section{CONCLUSION}

Copper transport through the A- and Bhorizon of Bojac sandy loam was associated with the mobility of TOC. Fulvic acids were the main organic compounds responsible for copper mobility. The copper mobility through A-horizon soil which had a higher organic matter content was greater than through B-horizon soil. The $\mathrm{pH}$ of the copper solution had a considerable effect; the mobility of TOC and copper was least at $\mathrm{pH}$ 4.24 and greater at $\mathrm{pH} 6.24$ and $\mathrm{pH} 7.24$. Ionic strength of the copper solution and the presence of chloride ions did not have a considerable effect on the copper mobility.

\section{REFERENCES}

[1] Alloway, B.J., Soil Processes and the behavior of Metals In: Heavy Metals in Soil, Edited by: Alloway B.J., Blackie Academic and Professional, London, 1995.

[2] Gallagher, D.L., Hohnston K.M. and Dietrich A.M., "Evaluation of Sedimentation as a Best Management Practice for Removing CopperBased Crop Protectants in Plasticulture Runoff", Water Research (in press), 2001.

[3] Dietrich, A.M., D.L. Gallagher and K.A. Klawiter, "Inputs of Copper-Based Crop protectants to Coastal Creeks from Plasticulture Runoff", J. American Water Research Assoc (in press), 2001.

[4] Gupta, G. and Karuppiah M., "Heavy Metals in Sediments of two Chesapeake Bay TributariesWicomico and Pocomoke Rivers", J. of Hazardous Materials, Vol. 50, 1996, pp. 15-29.

[5] Mullins, G.L., Martens D.C., Miller W.P., Konegay E.T. and Hallock D.L. "Copper availability, Form and Mobility in Soils from Three Annual Copper-Enriched Hog Manure Application", J. Environ Qual, Vol. 11 (2), 1982, pp. 316-320.

[6] Wan Zuhairi W.Y., Abdul Rahim Samsudin, and Nurita Ridwan, "The Retention Characteristics of Heavy Metals in Natural Soils using Soil Column Experiment", The 12th International Conference of International Association for Computer 
Methods and Advances in Geomechanics (IACMAG), Goa, India, 1-6 October 2008.

[7] Wilhelmy, Sergio A.S., Duaret I.R. and Flegal A.R., "Distribution of Colloidal Trace Metals in the San Francisco Bay Estuary", Geochimica et Cosmochimica Acta, Vol. 60 (24), 1996, pp. 4933-4944.

[8] Salam, D. and El-Fadel M., "Mobility and availability of copper in agricultural soils irrigated from water treated with a copper sulfate algaecide", Water, Air, and Soil Pollution, Vol. 195, (1-4), 2008, pp. 3-13.

[9] Lazerte, B., Evans D. and Graunds P., "Deposition and Transport of Trace Metals in an Acidified Catchment of Central Ontario", The Science of the Total Environment, Vol. 87-88, 1989, pp. 209-221.

[10] Kuo, W.C. and Parkin G.F., "Characterization of Soluble Microbial Products from Anaerobic Treatment by Molecular Weight Distribution and Nickel-Chelating Properties", Water Res., Vol. 30 (4), 1996, pp. 915-922.

[11] Huang, B.G., Jun K.S., Lee Y.D. and Lung W.S., "Importance of DOC in Sediments for Contaminant Transport Modeling", Water Sci. Technol, Vol. 38 (11), 1998, pp. 193-199.

[12] Guan TX, He HB, Zhang XD, Bai Z., "Copper fractions, mobility and bioavailability in soilwheat system after Cu-enriched livestock manure applications", Chemosphere, Vol. 82(2), 2011, pp. 215-22.

[13] Thompson, Michael L. and Scharf R.L., "An Improved Zero Tension lysimeter to Monitor Colloid Transport in Soils", J. Environ. Qual. Vol. 23, 1994, pp. 378-383.

[14] Borg H. and Johansson K., "Metal Fluxes to Swedish Forest Lakes", Water, Air and Soil Pollution, Vol. 47, 1989, pp. 427-440.

[15] Grout, H., Wiesner M.R. and Bottero J.Y., "Analysis of Colloidal Phases in Urban StormWater Runoff", Environ. Sci. Technol, Vol. 33, 1999, pp. 831-839.

[16] Doner, H.E., "Chloride as a Factor in Mobility of $\mathrm{Ni}$ (II), Cu(II) and Cd(II) in Soil", Soil Sci. Soc. Am. J., Vol. 42, 1978.

[17] Howell, J.M. and J.M. Gawthorne., Copper in Animals and Man, Vol. 1, CRC Press, Inc, Boca Raton, Florida, 1987.
[18] Bahaminyakamwe L., Simunek J., Dane J.H., Adms J.F. and Odom J.W., "Copper mobility in soils as affected by sewage sludge and low molecular weight organic acids", Soil Science, Vol. 171 (1), 2006, pp. 29-38.

[19] Igloria, R.V., Hathhorn W.E., Member, ASCE and D.R. Yonge, "NOM and Trace Metal Attenuation During Storm-Water Infiltration", Journal of Hydrologic Engineering, Vol. 2 (3), 1997, pp. 120-127.

[20] Sposito, G., "Sorption of Trace Metals by Humic Materials in Soils and Natural Water", RC Review in Env. Control, Vol.6 (2), 1986, pp. 193-229.

[21] Brown, S., R. Chaney and J.S. Angle, "Suburface Liming and Metal Movement in Soil Amended with Lime-Stabilized Biosolids", J. Environ. Qual., Vol. 26, 1997, pp. 724-732.

[22] Biehn, C.A., "An Investigation of the Adsorption and Desorption Capacities of Bojac Sandy Loam Soil from the Eatern Shore of Virginia", M.S. Project Report, Blacksburg, VA, 1999.

[23] Page, A.L. ; Editor, Methods of Soil Analysis, Part 2; Chemical and Microbiological Properties, $2^{\text {nd }}$ Edition, American Society of Agronomy, Inc. and Soil Science Society of America, Inc. (publisher), Madison, Wisconsin, 1982.

[24] Newman, M.E., A.W. Elzerman and Looney B.B., "Facilitated Transport of Selected Metals in Aquifer Material Packed Column", Journal of Contaminated Hydrology, Vol. 14, 1993, pp. 233-246.

[25] Kuiters, A.T. and Mulder W., Metal Complexation by Water-soluble Organic Substances in Forest Soils; in metal Speciation, Separation and Recovery, Edited by James W. Patterson and R. Passino, Vol. 2, Lewis Publishers, 1989.

[26] McCarthy, J. and J. Zachara, "Subsurface Transport of Contaminants", Envir. Sci. and Technol, Vol. 23 (5), 1989, pp. 496-502.

[27] Karmer C.J.M. and Duinker J.C., "Complexing of copper by sediment extracted humic and fulvic material", Thalassia Jugoslavica, Vol. 16 (2-4), 1980, pp 251-258.

[28] El-Sayed M.A., Beltagy I.A, , Aboul Naga W.M. anf Yousef H., "Role of Humic Substances in the Accumulation of Trace Metals in Bottom Sediments", Proc. Symp. Mar. Chem. In the Arab Region. Suez, 1991, pp 239-254. 
[29] Stevenson, F.J. and Chen Y., "Stability Constant of Copper (II) Humate Complexes Determined by Modified Potentiometric Titration", Soil Sci. Soc. Am. J., Vol. 55, 1991, pp. 1586-1591.

[30] Zelazny, L.W., L.He and Vanwrmhoudt A., "Charge Analysis of Soils and Anion Exchange, Chapter41 in Methods of Soil Analysis", Part 3, Chemical Methods- SSSA Book Series, no.5, Soil Science Society of America and American Society Agronomy, pp. 1231-1253, 1996. 


\section{العو امل المؤثره علي حركة امتصاص مركبات النحاس خلال الطبقة (أ) والطبقة (ب) لتربة رملية طينية في الساحل الثرقي لفرجينيا

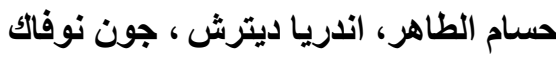 \\ قسم الهندسه المدنية و البيئيه, جامعه فرجينيا التقنيه, الو لايات المتحده الامريكيه}

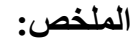

تم في هذا البحث دراسة حركة مركبات النحاس خلال الطبقة (أ) والطبقة (ب) من طبقات تربة رملية طينية. و اشتمل البحث على دراسة مستمرة ودر اسة دفعة. ثم دراسة تغير الأس الهيدروجيني والكربون العضوي الكلي وأحماض الدوباليه (الأحماض الهيومية) على حركة هذه المركبات. وقد وجد أن حركة مركبات النحاس أنشد في خلال الطبقة (أ) من طبقات التربة. كما وجد أن الأس الهيدروجيني له تأثير كبير على حركة هذه المركبات وكذلك على حركة مركبات الكربون العضوي الكلي.

وقد وجد أن أعلى معدل حركة عند قيمة الأس الهيدروجيني قدر ها 6.24 كما أن حركة هذه المركبات في كلتا الطبقتين مرتبطة بحركة المركبات العضوية الكربونية الكلية. وبمقارنة المركبات الدوبالية مع المركبات الفولفية وجد أن الأخيرة لايها قدرة على امتصاص مركبات النحاس أعلى بأربعة مرات من المركبات الدوبالية وقد تم تفسير حركة مركبات النحاس في التربة بمقارنة حركة المركبات العضوية والأحماض الفولفية في التربة. 